Western University

Scholarship@Western

Management and Organizational Studies

Management and Organizational Studies

Publications

Department

6-29-2015

\title{
The perils of project-based work: Attempting resistance to extreme work practices in video game development
}

Amanda Peticca-Harris

Grenoble Ecole de Management

Johanna Weststar

Western University, weststar@uwo.ca

Steve McKenna

York University

Follow this and additional works at: https://ir.lib.uwo.ca/mospub

Part of the Business Administration, Management, and Operations Commons, and the Work, Economy and Organizations Commons

\section{Citation of this paper:}

Peticca-Harris, Amanda; Weststar, Johanna; and McKenna, Steve, "The perils of project-based work: Attempting resistance to extreme work practices in video game development" (2015). Management and Organizational Studies Publications. 20.

https://ir.lib.uwo.ca/mospub/20 


\section{Western University}

From the SelectedWorks of Johanna Weststar

2015

The perils of project-based work: Attempting resistance to extreme work practices in video game development

Amanda Peticca-Harris

Johanna Weststar

Steve McKenna, York University 


\title{
The perils of project-based work: Attempting resistance to extreme work practices in video game development
}

\author{
Amanda Peticca-Harris, York University \\ Johanna Weststar, Western University \\ Steve McKenna, York University \\ A fully edited, peer-reviewed version of this article is available from Organization. Please cite \\ as follows:
}

Peticca-Harris, A, Weststar, J. and McKenna, S. (2015). The perils of project-based work: Attempting resistance to extreme work practices in video game development.

Organization, 22(4): 570-587. DOI 10.1177/1350508415572509.

\begin{abstract}
This article examines two blogs written by the spouses of game developers about extreme and exploitative working conditions in the video game industry and the associated reader comments. The wives of these video game developers and members of the game community decry these working conditions and challenge dominant ideologies about making games. This article contributes to the work intensification literature by challenging the belief that long hours are necessary and inevitable to make successful games, discussing the negative toll of extreme work on workers and their families, and by highlighting that the project-based structure of game development both creates extreme work conditions and inhibits resistance. It considers how extreme work practices are legitimized through neo-normative control mechanisms made possible through project-based work structures and the perceived imperative of a race or 'crunch' to meet project deadlines. The findings show that neo-normative control mechanisms create an insularity within project teams and can make it difficult for workers to resist their own extreme working conditions, and at times to even understand them as extreme.

Keywords: extreme work, project-based work, viedo game development, work-life balance, normative control
\end{abstract}




\section{Introduction}

The global video game industry is booming. Successful games are highly lucrative, with examples such as Call of Duty: Modern Warfare 3, grossing more than US\$775 million in its first week on the market (Rose, 2011). High-profile successes along with a culture of fun, innovation and creativity generate an industry stereotype that suggests that video game developers get paid to play (de Peuter and Dyer-Witheford, 2005; Deuze, Martin and Allen, 2007). This stereotype overshadows a different reality; the game industry is faced with intense and extreme working conditions.

This paper highlights the 'dark side' of the game industry by examining two online whistleblowing web logs (blogs) written by the spouses of video game developers, as well as their accompanying reader comments. In particular, we bring attention to the extreme work conditions that prevail in the industry, but also examine how people other than the workers are challenging them. The first blog, 'The Human Story' (posted under the tagline 'ea_spouse'), discusses the working environment at the Electronic Arts Los Angeles studio during the making of the Lord of the Rings video games in 2004. The second blog, 'Wives of Rockstar San Diego employees have collected themselves' (posted under the tagline 'Rockstar Spouse'), discusses the working environment at Rockstar San Diego during the making of Red Dead Redemption in $2010 .{ }^{1}$

Extant studies on work intensification have attempted to quantify the nature of work intensification by measuring the increase or decrease of work hours and have also sought to identify the associated consequences of intense work conditions (see Brett and Stroh, 2003;

\footnotetext{
${ }^{1}$ In the case of both data sources, the full, original blogs and comments can be accessed online as follows: EA Spouse: http://easpouse.livejournal.com/274.html; Rockstar Spouse http://www.gamasutra.com/blogs/RockstarSpouse/20100107/4032/Wives of Rockstar San Diego employees have collected themselves.p hp A summary of the episodes and surrounding media coverage can be found at the Game Quality of Life website created by one of the authors: http://gameqol.org/category/archives/
} 
Burchull and Fagan, 2004; Green, 2001; Hewitt and Luce, 2006). This paper extends the discussion of work intensification by examining some of the mechanisms that perpetuate and normalize work intensification. We also consider how worker's families resist these working conditions, and explore the impact of this resistance at an industry level. We specifically contribute to the work intensification literature in three ways. First, we add to the literature concerning the negative toll of extreme work on workers and, more importantly, on the families of workers (Dembe et al., 2005). Second, we consider an alternative view of the game industry that challenges two myths: the façade that 'work is play' and that long hours are necessary and inevitable to make successful games. Third, we argue that the project-based nature of video game development acts as a mechanism of control that both creates extreme working conditions and also inhibits sustained resistance to those conditions among those experiencing them. As such, we illustrate how peripheral voices (Westecott, 2013) might be necessary to challenge the dominant norms of working conditions in game development.

The paper begins with an overview of the work intensification literature. We introduce here the context within which work intensification is taking place, where the 'intelligent' North American middle class is under increasing pressure to perform against a backdrop of precarious employment (see Beck, 2000; Kalleberg, 2009; Vosko, 2000). We expand on the notion that the project-based management system that dictates the daily experiences of game workers, acts as a neo-normative control mechanism that harnesses passion and positions work as play, in order to leverage worker energy for the good of the project and the team (and organization) (Sturdy et al., 2010). This is followed by an overview of the data and methodology and a discussion of key findings in the form of blog and comment excerpts. 


\section{Work intensification and Video Games}

Issues related to extreme work, including long hours and work intensity, have attracted considerable attention from researchers with respect to the origins, prevalence, causes and consequences (both positive and negative) of such work practices (Burchell and Fagan, 2004; Burke, 2007; Burke and Cooper, 2008; Burke et al., 2010; Eastman, 1998; Green, 2001, 2004, 2008; Feldman, 2002; Felstead et al., 2013; Fiksenbaum et al., 2001). "Working hard" is conceptualized as having both a time component (e.g. the number of hours required to do a job) and an intensity component (e.g. the level of intensity or effort required to do a job) (Green, 2001). Work intensity, therefore, encompasses both the extensive component of hours worked as well as the intensive component of pace and/or effort required to do the work. While these studies provide a foundation to understand work intensification, they refer to working conditions and work context of 10-15 years ago. Our paper further explores how long hours have come to be normalized and legitimized, but also examines how they are simultaneously challenged and resisted in the current working context, specifically in the game industry.

A central question in the work intensification literature seems to be whether individuals are working long hours, or being tolerant of intense work environments due to personal choice and love of their work (Campbell and van Wanrooy 2013; Sturges, 2013) or if they are "conscripts" (Drago et al., 2009), working long hours due to external forces. In their mixed method study about long work hours and preferences among professionals and managers, Campbell and van Wanrooy (2013: 1149) found significant ambivalence and uncertainty in workers' attitudes toward their long hours. The authors conclude that workers hold multiple conflicting views that are often connected to workers' sense of the feasibility of another option (fewer hours) and workers' difficulty in "identifying indirect pressures" that keep them at work. 
When direct command or control was absent, workers attributed their long hours to personal choice.

Similarly, Sturges (2013: 349-352) explores the indirect pressures that compel workers to work long hours. Drawing from interviews with a sample of young architects and construction engineers, Sturges suggests that workers may be ambivalent and/or tolerant of working long hours because of the meaning and intrinsic value that they have ascribed to their work. Some workers suggested that the extra effort and long hours were necessary to become part of the "work family," be able to work on interesting projects, or to learn and advance in a field that goes "hard and fast".

In the context of this study, video game developers almost universally love their work (Legault and Weststar, 2012), yet there are a growing number of reports about long, uncompensated working hours under 'make it or break it' conditions. According to recent survey data from the International Game Developers Association (Legault and Weststar, 2012; Weststar and Legault, 2012), the average game developer works between 35-50 hours in a regular week and 45-70 hours when in a period of crunch or race to project completion. However, many game developers seem to accept these conditions and are often very positive about the work that they do. A majority surveyed felt that their career in game development was 'their life' or a large part of it. A quarter of the sample reported that any sacrifices that they make for their job are worth it; $35 \%$ felt that crunch is a necessary part of game development and see it as a normal part of scheduling.

Moreover, the product 'cool-factor' of big budget video games conceals a highly secretive, competitive, and largely risk-averse industry (O’Donnell, 2009). Top tier console games can cost over US\$30 million to produce, yet less than $10 \%$ of video games shipped break 
even (IGDA, 2004: 42). While some survey evidence shows a high degree of satisfaction among game developers, research into the relationship between intense work and satisfaction has produced conflicting results. For instance, work intensity has been associated with negative consequences such as physical exhaustion and mental stress (Green and McIntosh, 2001). Video game workers in particular face issues of unlimited and unpaid overtime, poor work-life balance, musculoskeletal disorders, burnout, non-compete and non-disclosure agreements, and limited or unsupported training opportunities (Deuze, Martin and Allen, 2007; Dyer-Witheford and de Peuter, 2006; Legault and Weststar, 2014)

\section{'Crunch' as a neo-normative control mechanism}

The indirect pressures that elicit and sustain long work hours among technical, professional and managerial employees, ostensibly through personal choice, can also be understood as a neo-normative control mechanism (Fleming and Sturdy, 2009). As an extension of normative control, where workers are encouraged to conform to a rigid organizational culture and structure, through neo-normative control, workers are also now extolled to "be themselves" and bring more of their "authentic selves" to the workplace (Fleming and Sturdy, 2009: 570). The exhortation for workers to be individuals and authentic selves at work goes hand in hand with the expectations for workers to be individuals in the market, to be self-reliant and shoulder the risk of maintaining their own employability (Webb, 2004). Within this context, having 'real' fun at work so as to build authentic positive social networks while individually interpreting and enacting the professional norms of one's occupation are key signals of careerism and drivers of career progression (Neff, 2012).

At one level, the success of neo-normative control mechanisms can be explained through 
Schor's (1991) theory of positional competition. This theory suggested that employees might be caught in a competitive 'rat race', striving for organizational advancement and material success by working long hours. In striving for advancement and material gain they are often frustrated and unhappy because of a lack of balance in their lives, while being committed to their career and satisfaction at work (Peticca-Harris and McKenna, 2013; Schor, 1991). However, while helpful, the idea of the 'rat race' is not in itself enough to understand the power of neo-normative control mechanisms. Competition among the aspirational middle class is a requirement for "capital's circuit of control" (Willmott, 1997: 1354) and an organizing principle in the cultural market of immaterial labour (Lazzarato, 2006). Here, the precarious nature of project-based work masks the neoliberal discourse and shifts expectations of loyalty and responsibility from the organization towards personal responsibility for one's own job stability and career (Dardot and Laval, 2013; Sennet, 2011).

Unlike typical operations-based management carried out by a consistent and stable set of employees, project-based organizations (or project management departments within organizations) engage in cycles of hiring, firing and reallocation that correspond to stages of finite projects. In this environment firms bring on workers in a variety of employment relationships for various purposes at various times that are all dictated by the specifications of the project (Cicmil and Hodgson, 2006; Hodgson, 2004). Within this environment, the irontriangle of resource constraints (budget, schedule, scope) are paramount drivers in the lives of project team members (Chasserio and Legault, 2009; Legault and Bellemare, 2008; Zackariasson et al., 2006). These constraints lift the project, and the client, to a position of an all-powerful entity (Cicmil et al., 2006; Hodgson, 2002; Hodgson and Cicmil, 2007). The workers' task is to complete the project to the client's satisfaction by any means necessary (whether that is a game 
publisher, a movie producer, an external organization, etc.). As a consequence of such features, project-based work is inherently precarious (Hodgson, 2004). So-called 'permanent workers' have no guarantee that they will be retained or reassigned following the end of a particular project stage, and contract workers are hired only for specific components of a project with no promises of renewal or permanence. In such an environment, the individual employee is always sensitive to the need to maintain employability.

Neff (2012) argues that increased job insecurity in project-based 'creative' or 'knowledge' industries, encourages employees to make venture labor investments; that is personal investments of their time, energy, human capital, and other personal resources. In turn, dependent wage earners come to act like entrepreneurs or business owners, though they are not. In this context employers feed off workers' fear of failing and fear of falling (Ehrenreich, 1989). This enables greater control and exploitation of workers who are "rendered anxious" by their career prospects and are "obsessively concerned about their individual performance, job security, career prospects" (Willmott, 1997: 1347; also Peticca-Harris and McKenna, 2013) as their peer and portfolio-based reputations are a critical factor in their career success.

In video game development, work can be perceived as precarious because it operates under project-cycles and portfolio-based mobility (Weststar and Legault, 2012). The "circuit of control" may be intensified in an industry where primarily young workers willingly invest their venture labor into game development because of their passion and their love of games and game making (O'Donnell, 2009). As a consequence of the blurring of work and play (Kane, 2004) and the vague idea to answer your calling, 'follow your heart', and 'do what you love', managers may be better able to capitalize on and exploit employee's private hobbies and passions. Sturdy et al., (2010) argue that harnessing passion for the purposes of exploitation works in combination with 
traditional forms of control such as surveillance, participation, autonomy, and shared interests (Barker, 1993; Burawoy, 1985; Delbridge and Ezzamel, 2005; Sewell, 2007). They suggest that there is an "elaboration rather than reversal of bureaucratization" (Sturdy et al., 2010: 115) at an industry level.

With this rise in the entrepreneurialization of work, employees expect to receive little from their organizations other than remuneration and the opportunity to develop their skills and portfolios for subsequent use in competitive markets (Sturdy et al., 2010). Even then, industry workers may take the bait and invest in their studios by deferring aspects of compensation in exchange for potentially lucrative rewards in the future and promote products/services in their off-hours (e.g. playing games) to support company goals and generate new demands (Neff, 2012).

Game development as part of this discourse, has been called a "soft coercive system" (Whitson, 2013: 124). Both Whitson (2013) and O’Donnell (2009) suggest that video game developers come to their work with the idealized desire to 'play' - to solve the puzzles of game making and to push the genre they love to new heights. However, both also conclude that capitalist drivers - "monetization, marketing and advertising needs" (Whitson, 2013: 125) create an environment that turns this very desire against game developers. As such, the capitalist constraints are shared in both mainstream and independent/indie studios with independent game studios competing with the large-scale publishers and manufacturers that dominate the industry (Consalvo, 2006; Johns, 2006, Kerr, 2006; Williams, 2002) and increasingly with each other in a crowded marketplace. Indie studios are not shielded from the exploitation and precarious nature of work as they too operate under the project-management regime and encounter the same churn of talent associated with the completion of project cycles and creation of new titles. As Westecott 
(2013) wrote and blog commentators in our study also noted, cross-fertilization between indies and 'AAA' studios risks that the dominant normative practices - how people were taught to make games in the large studios - colonize the new space.

As Lazzarato (1996: 136) wrote, “precariousness, hyperexploitation, mobility, and hierarchy are the most obvious characteristics" of the immaterial labour that includes video game development. Though Lazzarato (1996) wrote with contract or temporary labour in mind, the arguments presented above show that dependent wage labourers might be included in this group of precarious intellectual workers. This is particularly so because of the high mobility of projectbased work (see O'Riain, 2001 for a description of software developers). The flexible, shortterm, project-based cycles and the utmost need for successful project outcomes, due to reputation-based mobility, shift managerial responsibilities onto employees. Under the illusion of empowerment employees monitor themselves and their peers (Neff, 2012) as they bend to accommodate the inflexibility of project deadlines. As O'Riain (2001) describes, as the deadline for the project milestones approaches, the team becomes insular - singularly focused on satisfying the project at all costs. Rather than issuing overt managerial dictates, management appeals to the needs of the project, channeling and accentuating the latent professional norms and intrinsic commitments to the work. In other words, management need not say "I need you to work late tonight" but rather "The project requires you to work late." Workers wish to be a strong team member within their 'work family' (Sturges, 2013), and earn client esteem by producing a quality project within the iron triangle of constraints. While there remains reliance on intraorganizational regimes such as corporate culture policing, project "crunch" acts as an interorganizational governance structure or value-based control that is market-based and decentralized throughout the industry (Thomas, 2003). 
In summary, video game developers are project-based workers who may love their work, but are controlled by the neo-normative control mechanisms of the deadline and individualized angst about career prospects and employability. While there is very little resistance to extreme working conditions among game developers, aside from quitting (Legault and Weststar, 2013), there has been significant albeit "decaf resistance" (Contu, 2008: 370) on the part of others in the game community. Here, Contu refers to a form of safe resistance that can be practiced without paying the full cost of the risks to whistle blow. In the remainder of this paper we illustrate how the developer's spouses and broader game community challenge the extreme working conditions with our analysis of two impactful blogs and their associated reader comments. While this resistance does not come from a place of duty or radical freedom but rather, self-interest and utility (Contu, 2008: 375), we highlight how even 'decaf resistance' can garner legal attention and spark industry change.

\section{Methodology}

\section{Data Collection}

The data for this study consists of two blogs and additional comments posted anonymously on the Internet by their authors (EA Spouse and Rockstar Spouse). Blogs are generally defined as frequently updated websites consisting of dated entries arranged in reverse chronological order (Walker Rettberg, 2008). Blogs allow dialogue or co-production between authors and readers in the form of comments, while the author retains ownership of and, ultimate control over, the blog's content (Hookway, 2008). Blogs offer an unadulterated first-person perspective and that often has a confessional quality or represents alternative voices on the subjects/topics addressed (Hookway, 2008). 
The first blog is entitled 'The Human Story' and was posted using the free blogging software Live Journal under the tagline 'ea_spouse' on November 10, 2004. The blog discussed the working environment at an Electronic Arts studio in Los Angeles during the making of the Lord of the Rings video games. EA Spouse was the first major exposé of the game industry and targeted one of the largest developer-publishers. The blog went live in the middle of a class action lawsuit by programmers against Electronic Arts where the plaintiffs were ultimately awarded US\$15.6 million in unpaid overtime (Surette, 2006). It was revealed later that EA Spouse is Erin Hoffman, the wife of one of the lead plaintiffs in the class action suit. While game developers were the plaintiffs in the class action suit, Erin Hoffman is credited with initiating a 'Quality of Life' movement in the industry (Remo, 2010).

The second blog is entitled 'Wives of Rockstar San Diego employees have collected themselves' and was posted on January $7^{\text {th }}, 2010$ on the Gamasutra Blogs webpage (the premier electronic magazine for the game industry) under the tagline 'Rockstar Spouse'. This blog mimics the format and messaging of EA Spouse and discusses the working environment at Rockstar San Diego during the making of Red Dead Redemption. It spurred the International Game Developers Association to issue a statement to Rockstar San Diego Studios about 'appropriate' balance in working hours (IGDA, 2010).

These blogs were selected for two reasons; first, each blog 'went viral' in the video game community and then spread to other media outlets. Second, both blogs represent an oppositional and alternative voice to the rhetoric surrounding the game industry's 'cool factor'. The blogs present another side of the game industry, including worker and family frustrations as they highlight some of the extreme practices in which the industry engages. The blogs act as a subtle 
form of resistance, albeit one that has ignited discussions about industry-wide changes to working practices.

\section{Analysis}

The blogs were analyzed to locate the narrator's perception of the situation within a wider structural and discursive context (McKenna, 2010). Here, blogs act as a forum through which the narrator (the blog writer) can express emotions and feelings about their lives (Boudens, 2005; McKenna, 2007). Blogs as a narrative, not only represent things in the world; they also have an interactional function and position the writer in a web of voices and relationships with others. While a blog may describe a situation, it also introduces alternative voices, discourses and narratives. In the case of these two blogs, the writers engage with a broader context in such a way as to raise questions about injustice and exploitation in a particular aspect of organizational or social life.

The blogs were analyzed thematically (King, 1998; Riessman, 1993) using NVIVO qualitative data management software. The researchers independently coded the data for main sub-themes within the over-arching narrative of extreme work, and then collectively reconciled the list of themes. This process resulted in the identification of four dominant sub-themes: quality games, crunch (sustained overtime), project-based control, health issues and family conflict. These themes were then applied to the categorization and classification of the blog comments. Due to their volume, only a portion of the 4811 comments was formally coded. All of the 152 Rockstar Spouse comments were coded and approximately 10\% of the EA Spouse comments were coded beginning on page 1 . For the latter, coding continued until a point of 
saturation for the identified central themes was reached. In addition to the sub-themes listed above, the comments were also categorized as being 'supportive' or 'unsupportive' of the tenor of the respective blog. From here, we bundled sub-themes into three parent nodes: project-based work regimes, game quality and crunch, and health issues and family conflict. The intent of the analysis and its resulting presentation below is not to provide an objective count of people who experienced certain conditions, but rather to provide excerpts that exemplify and support the various positions within the debate. Given the public nature of the blogs and comments, all names have been kept in the format as they appear on the blog post and comments. Inherent in blogging is the paradox that people are able to write for an audience but remain as anonymous as they desire (Hookway, 2008).

\section{Findings and Discussion}

\section{Project-based Work Regimes}

The blogs and comments illustrate that the dominance of extreme work within the game industry is shaped and perpetuated by the project-based structure of the work. As discussed by Hodgson $(2002,2004)$ and Cicmil et al. (2006) and described with respect to software designers by O'Riain (2001), workers are controlled both structurally and normatively under projectmanagement regimes. Due to the inherent mobility of project-based work, workers must rely on their portfolios and their reputations to maintain employability. As such, a worker's personal choice to work long hours is often constrained by the social context, institutional conditions and social rights involved (Crompton and Harris, 1998; McRae, 2003). As Sturges notes, "working long hours was the time when people felt closest to their work 'family"' (2013: 354); yet the development of a family atmosphere that blurred the boundary between work and play was "a 
deliberate attempt by the firm founder to ... encourage employees to work long hours when required" (2013: 353). This elevates the power of reputation-based norms such as being part of the team or work family (Sturges, 2013) and, as illustrated in numerous comments to both the EA and Rockstar Spouse blogs, making sacrifices to have a successful game on your resume:

From a spouse of a RSSD [Rockstar San Diego] employee: ...To our potential consumers: DO NOT BOYCOTT THIS GAME! If you do, all their hard work would have been for nothing. Support your fellow artists and buy their game. Thank you. (will's mom, 2010-01-12, 12:05pm, Rockstar Spouse)

The power of the project and the ability for management to subsume their demands in the supposed needs of the project is also an important form of control. The parameters of budget, deadline and scope are understood to be written in a contract from the beginning of the project, yet the blogs and comments indicate that the front line workers are often unaware of the true big picture of the game; they face externally imposed changes in the scope throughout the development process, and they are often threatened with cancellation of the contract due to budgetary constraints or insufficient progress at milestone check-points. This creates a downward pressure on the team where the only outlet is to work longer and harder. EA Spouse and Rockstar Spouse reject this and argue that project crunch is not a natural phenomenon associated with this type of work, but a product of poor and exploitative management. As described by Rockstar Spouse, "The managers at Rockstar San Diego continue in their dishonesty, pushing their employees to the brink promising temporariness fully equipped with the knowledge of another deadline just around the corner." And by EA Spouse, "Crunching neither accelerated [the schedule] nor slowed it down; its effect on the actual product was not measureable. The extended hours were deliberate and planned; the management knew what they were doing as they did it." 
Yet, as O'Riain (2001) argued, the power of the deadline directs the project team to the singular purpose of completing the project in the face of all challenges:

It is too late to change anything now. The game has to ship on the ship date, this can't be changed. It will need more than 40 hours/week by everybody to finish. All I can ask: Please stop adding more features. We need to ship the game. Please stop making more big changes. We need to ship the game. (John Marston, 2010-01-10 9:22 pm to Rockstar Spouse)

One commentator critiques the insularity and inevitability of these control mechanisms and raises the issue of resistance:

The problem here really is: is anyone in the team willing to step forward and say: whatever we've been working on for so long, so hard which is finally coming together quite nicely - let's just throw it away and call it off. It's not worth the sacrifice. That person would be looked upon as an outcast. How could he ever think that? And quit now? Yes, the conditions aren't the best BUT the game is almost finished and looking really cool now...There's a very strong reinforcement / influence cycle going on in situations and teams like these. Which is why, after all, the spouses are the ones crying out for help in favor of their beloved ones! That should tell (all of us) something! (Steffen Itterheim, 2010-01-12, 3:07pm, Rockstar Spouse)

This excerpt draws attention to the notion that the structural and normative control mechanisms of project-based regimes inhibit resistance by the workers within those regimes and requires the actions of outsiders (in this case the spouses). Some workers do resist in individual ways:

I remember very clearly the day the game shipped...I broke down because it felt like I had just been released from prison. After shipping that game, I resolved to never EVER let any company abuse my willingness to be a good employee (John Nagle, 2010-01-24, 9:02am, Rockstar Spouse).

Post-project catharsis and the feeling of having survived and solved all the creative puzzles is also a powerful influence in the overall control mechanism of project-based work, 
particularly when the project is a success (O'Riain, 2001). A particularly active commentator on the Rockstar Spouse blog was clearly a current employee of Rockstar. His early posts said much about the challenges the team faced and he criticized the role of management. However, in posts made after the game had shipped, he was conciliatory, citing the promises management had made that this would never happen again, describing the time off that was given, and apologizing for his earlier comments.

Another commentator asked the critical, yet perhaps rhetorical, question, "So RDR came out and Metacritic'ked at $95^{2}$. Does this mean $\mathrm{R}^{*}$ are vindicated for their production culture?" (Emmeline Dobson, 2010-05-21, 2:47am, Rockstar Spouse) In the face of project completion and success, the cycle of exploitation continues; the investment of time and resources acts as a form of manufactured consent (Burawoy, 1979; Jacques, 1996). While workers derive satisfaction from what they do, they are caught in the bind of having to continue to do it under pressurized and exploitative conditions because their advancement and recognition depends on their exploitation - this is "capital's circuit of control". According to Neff (2012) this venture labor investment of personal time and resources into the project-work career binds workers closer to the organization and industry. As one developer warns, "The light at the end of the tunnel may end up being a train... especially if they [management] fall over themselves to promise otherwise." (Ted Brown, 2010-01-08, 3:17pm, Rockstar Spouse) In the context of these blogs, it is important to note that the families and friends of these exploited workers do not experience the catharsis and team-building; they remember better the bad times and are in a better position to label the cycle of exploitation for what it is.

\footnotetext{
${ }^{2}$ Metacritic is a website that aggregates reviews for film, television and games to assign an overall percentage score. A score of 90-100 for games indicates universal acclaim. http://www.metacritic.com/
} 


\section{Game Quality and Crunch}

EA Spouse and Rockstar Spouse did not write their blogs to simply tell a story about poor working conditions and their impact. Rather, the narrators position their blogs as a challenge against the dominant discourse and assumed norms of how video games are made; challenging the notion that crunch is required to create good games. In doing so they each create a rare moment, particularly at the time of EA Spouse, to allow the multivocality or multi-voicedness of industry actors to come forward and present alternative viewpoints (Bakhtin, 1981; Wortham, 2001). For instance, the Rockstar Spouse authors demand a "necessary rejoinder, in the form of an immediate action to ameliorate conditions of employees" from management and voice the exploitation and manipulation of employees by "certain hands that wield the reigns [sic] of power in Rockstar San Diego.” EA Spouse explicitly engages in a dialogue with the executive team of Electronic Arts: "To any EA executive that happens to read this, I have a good challenge for you: how about safe and sane labor practices for the people whose backs you walk for your millions."

The prevailing industry perspective is that extreme and intense working conditions are justified and required to ship a title. The blogs demonstrate the search for an alternative truth and attempt to refute the existence of extreme or intense working conditions, but more specifically, they question the inevitability and the necessity of these conditions to make successful, innovative games. This debate garners ample attention in the reader comments. The dominant voice is readily apparent in the comments that we coded as 'unsupportive' of or 'unsympathetic' to the EA Spouse and Rockstar Spouse blogs. These comments tended to fall into three groups. The first were those who said that they worked in hard jobs too and therefore had no sympathy for game developers: 
Here's the deal. I'll take your position. I served in the military, and I know about long hours. And I'll do better work than you do. I won't complain. I'll push myself as hard as humanly possible until I break, because I'm very aware of my breaking point. Once I've reached that point, I'll move on to another position or company. I live to take jobs from people like your spouse... Please, please keep on whining. It keeps me gainfully employed. (Anonymous, 2005-03-17, 02:40am, EA Spouse)

You babies have to stop crying and live in the real world. It's a dog eat dog world and we all need to just deal and if you can't deal, then get out of that type of business period. (Anonymous, 2004-11-30, 7:04pm, EA Spouse)

A second group of reader comments was comprised of those who generally felt that this was the state of the game industry and those who did not like it could find another studio to work for or leave the industry entirely.

"You're highly-skilled and feel your company is taking advantage of you? Leave. or better yet, make yourself better first and then move on"

I used to get emotionally stirred by the attitude of corporations and the treatment of their labor force, but nowadays, I employ the above quoted attitude. I give my employer what he wants, I take what I want, I find ways to take even more, then leave that employer for better opportunities elsewhere with the experience, knowledge and benefits I gained at my last job. Sure a lot of people aren't in the position I'm in (no children), but for those of you who are, don't hesitate to look elsewhere while you are still employed (just don't get caught, trust me!!! :0) (Anonymous, 2005-04-26, 5:46pm, EA Spouse)

Long hours is nothing new. I am a programmer@well know fps [first person shooter] gaming house. We work on average 15 hours a day including weekends. I'm sorry to say it but there is no getting away from this reality - if you wanna work in the gaming industy you have to "suck it down". Hey think of it like this get that office with a window \& you can gaze down on your red in the parkinglot :-). (Anonymous, 2004-11-20, 09:44:29, EA Spouse)

A third group of reader comments was comprised of voices with messages cautioning against resistance.

...unless you think you have a guaranteed win, you might want to reconsider challenging the guys with the big, expensive legal team. They are more than willing to spend more money than it would take to settle because it will prevent 
other teams in other branches from repeating the attempt to rebel. (Anonymous, 2004-11-15, 6:11pm, EA Spouse)

Game Developers: I caution you on posting details of internal affairs at your studio... If you bad mouth your employer in public, and your identity becomes public, not only will they fire you, but you will now have a reputation as a loose cannon that cant keep dirty laundry in house. If you ever get branded with this, NOBODY will ever hire you again. I have seen this happen on two occasions and in both cases, they never worked again in the game industry. (J T, 2010-01-12, 8:41pm, Rockstar Spouse)

In the first group, workers must pit themselves against each other in a contest for jobs and internalize the assumption that if they are struggling in a particular context, they don't deserve to be there. In the second group, workers must be ruthless entrepreneurs of the self and take all responsibility for their employability (Neff, 2012); they must take ownership of their choice to do certain jobs, accept the personal sacrifices and relish the material gains. In the third case, workers should be grateful for what they have, they should be fearful of the consequences of resisting and assume they are powerless if they try. The clustering of these 'unsupportive' categories into three groups serves to distinguish their arguments; however, they all serve to illustrate the strength of individualized employment relations that isolates the game developer as the problem.

\section{Health Issues and Family Conflict}

Supporting other research, an important sub-theme in the data was the negative impact of long hours on physical and psychological health (Burke and Cooper, 2008). EA Spouse and Rockstar Spouse document the toll paid by the development teams and these details are confirmed and expanded throughout the comment sections. Stress, burnout, depression, frustration, irritability, exhaustion, alcoholism, and suicidal tendencies were repeated themes. 
Rockstar Spouse criticizes the use of superficial techniques of 'stress management' saying, "[health problems] will not be ameliorated with a full time masseuse and will only worsen if no change to improve conditions take place and managers continue with their dishonesty of deadlines." The blog authors and other commentators seem to see this weak 'welfarism' response as insulting and voice management as dishonest in their concern, particularly when management belittles and resents the use of the health system in place (i.e., use of sick days). As noted in one comment:

The horrible part was, if you missed a day due to illness (even Saturday or Sunday), it would count against your TOPS time (time off pool.) (John Nagle, 2010-01-24, 9:02am, Rockstar Spouse).

The blog comments were also replete with references to the 'perks' that developers receive; they are provided with breakfast, lunch and dinner and "an endless supply of pop tarts and other sugar-laden coding fuels.” (John Nagle, 2010-01-24, 9:02am, Rockstar Spouse). These perks become important to the workers of the industry and eclipse management's responsibility for skirting health issues associated with sustained crunch. Perks act as a selling point to work in the industry because a company that buys you pizza and Gatorade and has donut Fridays is considered a 'cool' company. These perks are normative control tactics that lead workers to believe that the company cares about them and they act as a self-serving veil to the structural and managerial issues at the core of the intense work problem. As an ingrained norm, no one seems to question why workers are working so many hours in a day that the company would need to provide them dinner. And, in any case, pizza, donuts and Gatorade hardly qualify as a concern for the health of employees. 
The final theme of family conflict is not surprising, given that female spouses of game developers wrote both blogs. In the comments women reported and seconded the following: receiving flowers from studio management as appeasement for their husband's absence; eating dinner with their spouses at the studio to grab some quality time; and hearing their husbands apologize yet again for missing a family event. Numerous developer or ex-developer comments were punctuated with the confession of broken agreements with 'SOs' (significant others) around working hours and ultimately, broken relationships.

First, I made an agreement w/my SO that I would put in whatever hours I had to during the week so that I would not have to work weekends (this is before they started instituting mandatory 6-7 day work weeks). I got used to sleeping 5 to 6 hours a night so I could put in 14-16 hour days during crunch time. (Atomatom, 2004-11-12, 11:18am, EA Spouse)

It almost cost me my marriage, and I will never be in that position again if I can help it, so I am out of that line of work for good. I miss it on a certain level, but will never miss the massive amount of abuse I went through. (Christopher Spencer, 2010-01-20, 12:25am, Rockstar Spouse)

There's a reason to why games companies prefer to hire really young people without attached girl friends/wifes, I'm sure you can figure it out...(Anonymous, 2004-11-17, 5:43am, EA Spouse)

In addition, EA Spouse is explicit in the critique she directs towards the then CEO of Electronic Arts:

Larry, you do realize what you are doing, right? And you do realize that they ARE people, with physical limits, emotional lives and families right? Voices and talents and senses of humor and all that? That when you keep our husbands and wives and children in the office for 90 hours a week, sending them home exhausted and numb and frustrated with their lives, it's not just them you're hurting, but everyone who loves them? When you make your profit calculations and your cost analyses, you know that a great measure of that cost is being paid in raw human dignity, right? (EA Spouse)

Though EA Spouse is inclusive in her challenge by referring to husbands and wives, the impact 
of long work hours on the families of game developers is gendered. With male representation in core development roles (i.e., programming) at $85-90 \%$, it is overwhelmingly women who are performing the emotional and reproductive labour required to maintain the productivity of each male game developer (Westecott, 2013; see also Sturges, 2013). Numerous references to young workforces and having no children also show that success in this industry is built for a particular type of worker who has no other commitments. Despite their initial or on-going levels of support, unlike the game developers, the spouses and families do not experience a post-project catharsis (O'Riain, 2001) when the game ships and do benefit from the same intrinsic satisfaction from the work (Sturges, 2013). As such, the spouses and families may experience greater long-term damage from this type of work and, as seen in these two blogs, may be more inclined and able to resist and challenge industry standards.

\section{Concluding Remarks}

The dominant ideology and discourse of the game industry is a "no collar", postbureaucratic, high-tech bohemia (Ross, 2003) where game developers are able to follow their passion to produce successful games. However, extreme working conditions are a core feature of the game industry and have an immense impact on workers and their families. In this paper we surfaced alternative truths by examining two blogs written by the spouses of game developers in 2004 and 2010, and their associated reader comments.

At a micro level, the blogs are acts of whistleblowing that expose extreme working conditions at specific studios at specific times. At a more macro level, the blogs represent a conduit through which the spouses of game developers give voice to a fearful and exploited group of 'knowledge workers' who are caught in "capital's circuit of control" (Willmott, 1994) 
and unable or unwilling to speak for themselves (Contu, 2008). Taken together, the range of comments provides various alternative perspectives that challenge the broader context of the game industry. That said, while the blogs and comments do act as a safe forum to protest the extreme working conditions, they also provide space for the reiteration of dominant voices that protect the status quo. As noted above, these 'unsupportive' comments exemplify the argument that employment challenges have become individualized. They suggest that if a developer is struggling they are not working hard enough, or not cutout for the work. They shift blame for and normalize the working conditions by saying that it is a personal choice to do this type of work. And they disempower individuals by voicing the negative side effects of speaking out. These are the normative messages that workers face in their employment settings each day and further act to downplay resistance.

Capitalism has shown itself to be adept at manufacturing the compliance of workforces even under conditions where working life is precarious, uncertain, and insecure (Lazzarato, 2006, 2009). This insecurity of much of the current employment of project-based 'knowledge workers' or immaterial laborers is achieved through the neo-liberal promise of individual success and glory (Lazzarato, 2006, 2009). Here all hope of success and advancement in the marketplace is tied to the ability to compete and remain employable and this is tied to compliance. It is precisely this insecurity, this anxiety about employment and 'career' that allows exploitation through extreme work situations (Bradley et al., 2000). Real resistance and radical freedom (Contu, 2008) in this industry might mean workers lose their job with perhaps little hope of finding another.

Instead, a "softer resistance" (Contu, 2008: 375) is generated by the blogs and comments from outside of the workplace itself, from those impacted by these conditions and close to the 
game developers - spouses and members of the broader game community. Here, not only do the blogs act as a form of resistance, it is resistance that is articulated on behalf of another, their spouse. In this way, game developers are able to maintain their position in the rat race while improvements to working conditions are still being fought for and consciousness toward greater or more lasting change is being raised.

The challenges of extreme work in the game industry were not fixed by EA Spouse's outcry. This is clear given the emergence of the Rockstar Spouse blog eight years later. Indeed, online whistleblowing similar to EA and Rockstar Spouse has continued through journalistic exposés of the work practices at Team Bondi Studios in 2011 during the making of L.A. Noire and Trendy Entertainment in 2013 with the making of Dungeon Defenders II. As well, in 2012 “38 Studios Spouse" posted a blog about the mistreatment of her husband at 38 Studios when the studio went bankrupt shortly after releasing Kingdoms of Amalur: Reckoning. However, it can be argued that the blogs have both directly and indirectly contributed to material gains for developers.

The EA Spouse blog brought these issues to the public consciousness for the first time and subsequent outbursts fuel the debate and continue to promote material change within the industry. As noted above, the blog was published in conjunction with class action lawsuits regarding unpaid overtime in which Erin Hoffman (EA Spouse) was intimately involved. As such, the blog likely helped to surface additional claimants as well as increase the profile of the cases and bolster support from the game community. On numerous occasions, Hoffman replied to comments on her own blog inviting other EA employees to contact her directly, presumably to join the class action. The two suits, one for graphic artists and one for computer programmers (the latter led by Hoffman's fiancé Leander Hasty) challenged Californian law that exempted 
certain professionals employed in the software business from being paid time and a half for overtime hours. In both cases, the employees were successful; graphic artists received a settlement of \$15.6 million and programmers received \$14.9 million and many were reclassified. (Legault and Weststar, 2012). There is no available evidence of direct policy change at Rockstar, though posts to the blog following the release of the game speak of promises made and time-off (Legault and Weststar, 2013). Hoffman posted on the Rockstar Spouse blog asking anyone who had been reclassified as exempt from overtime, or who had seen reductions in pay or benefits to contact her, but no lawsuits materialized.

In a more indirect way, Hoffman remains a commentator on quality of life issues. For a time she maintained Gamewatch.org which was an online discussion forum to promote the selfpolicing of studio practices and her praise of studios which have undergone positive change also makes the game industry news. For instance, she applauded EA Tiburon for the studios improved working conditions during the making of NCAA and Madden NFL games and is now herself employed by an EA subsidiary (Sinclair, 2013).

In conclusion, the issue of extreme work remains a systemic problem in the game industry because of the structural and neo-normative control systems of competitive projectbased regimes. As demonstrated throughout our analysis, and in line with the work of Prasad and Prasad $(1998,2000)$ this socio-political context requires that resistance be often covert, informal, and mundane (Prasad and Prasad, 2000 as cited in Contu, 2008: 366). Social media has created a covert and informal space for game developers, their families, and consumers to be skeptical and cynical, to raise awareness, and give voice to the negative relationships between work and home, and about the nature of project-based work regimes. In this way, social media continues to show 
potential to be a tool in resisting the exploitative, extreme work conditions in the game industry "decaf" or not. 


\section{References}

Bakhtin MM (1981) The Dialogic Imagination C Emerson and M Holquist (trans). Austin: University of Texas Press.

Barker JR (1993) Tightening the Iron Cage: Concertive Control in Self-Managing Teams. Administrative Science Quarterly 38(4): 408-437.

Beck U (2000) The Brave New World of Work. Cambridge: Polity Press.

Boudens CJ (2005) The Story of Work: A Narrative Analysis of Workplace Emotion. Organization Studies 26 (9): 1285-1306.

Bradley, H., Erickson, M., Stephenson, C., and Williams, S. (2000). Myths at Work. Cambridge: Polity.

Brett JM, and Stroh, LK (2003) Working 61 plus hours a week: why do managers do it? Journal of Applied Psychology 88 (1): 67-78.

Burawoy M (1979) Manufacturing consent: Changes in the labor process under monopoly capitalism. University of Chicago Press.

Burawoy M (1985) The politics of production: Factory regimes under capitalism and socialism. London: Verso.

Burchell B and Fagan C (2004) Gender and the Intensification of Work: Evidence from the European Working Conditions Survey. Eastern Economic Journal 30: 627-42.

Burke RJ (2007) Research Companion to Working Time and Work Addiction. Cheltenham: Edward Elgar.

Burke RJ and Cooper CL (2008) The Long Work Hours Culture: Causes, Consequences, and Choices. Emerald Group Publishing: Bingley.

Burke RJ, Singh P, and Fiksenbaum L (2010) Work intensity: Potential Antecedents and Consequences. Personnel Review 39(3): 347-360.

Campbell I and van Wanrooy B (2013) Long working hours and working-time preferences: Between desirability and feasibility. Human Relations 66(8): 1131-1155.

Chasserio S and Legault M (2009) Strategic Human Resources Management is Irrelevant when it comes to Highly Skilled Professionals in the Canadian New Economy! International Journal of Human Resource Management 20(5): 1113-1131.

Cicmil S and Hodgson D (2006) New possibilities for project management theory: A critical engagement. Project Management Journal 37(3): 111-122. 
Cicmil S, Williams T, Thomas J and Hodgson D (2006) Rethinking Project Management:

Researching the Actuality of Projects. International Journal of Project Management 24: 677.

Consalvo M (2006) Console video games and global corporations Creating a hybrid culture. New Media \& Society 8(1): 117-137.

Contu A (2008) Decaf resistance: On misbehavior, cynicism, and desire in liberal workplaces. Management Communication Quarterly 21(3): 364-379.

Crompton R and Harris F (1998) Explaining women's employment patterns: 'orientations to work' revisited. British Journal of Sociology: 118-136.

Dardot P and Laval C (2013) The new way of the world: on neoliberal society. London: Verso.

Delbridge R and Ezzamel M (2005) The strength of difference: contemporary conceptions of control. Organization 12(5): 603-618.

Dembe AE, Erickson JB, Delbos RG and Banks SM (2005) The Impact of Overtime and Long Work Hours on Occupational Injuries and Illnesses: New Evidence from the United States. Occupational and Environmental Medicine 62: 588-97.

de Peuter G and Dyer-Witheford N (2005) A Playful Multitude? Mobilising and Counter Mobilising Immaterial Game Labor. FibreCulture Journal, 5.

Deuze M, Martin CB and Allen C (2007) The Professional Identity of Gameworkers. Convergence: The International Journal of Research into New Media Technologies 13.

Drago R, Wooden M, and Black D (2009) Long work hours: Volunteers and conscripts. British Journal of Industrial Relations 47(3): 571-600.

Dyer-Witheford N and de Peuter G (2006) "EA Spouse" and the Crisis of Video Game Labour: Enjoyment, Exclusion, Exploitation, Exodus. Canadian Journal of Communication 31(3).

ea_spouse (2004) The Human Story. In: livejournal. Available at: http://easpouse.livejournal.com/ (accessed September 1, 2012).

Eastman W (1998) Working for Position: Women, Men and Managerial Work Hours. Industrial Relations 11: 51-66.

Edwards K, Weststar J, Meloni W, Pearce C and Legault MJ (2014) Developer Satisfaction Survey Summary Report - 2014. Mt. Royal, NJ: International Game Developers Association. Available at http://gameqol.org

Ehrenreich B (1989) Fear of Falling: The Inner Life of the Middle Class. New York: Pantheon books. 
Felstead A, Gallie D, Green F and Inanc I (2013) Skills and Employment Survey 2012: Technical Briefing. London: Centre for Learning and Life Chances in Knowledge Economies and Societies, Institute of Education.

Feldman D (2002) Managers' Propensity to Work Longer Hours: A Multi-Level Analysis. Human Resource Management Review 12: 339-57.

Fleming P and Sturdy A (2009) “Just be yourself!": Towards neo-normative control in organisations? Employee Relations 31(6): 569-583.

Fiksenbaum L, Jeng W, Koyuncu M and Burke R (2001) Work Hours, Work Intensity, Satisfactions and Psychological Well-being among Hotel Managers in China. Cross Cultural Management: An International Journal 17(1): 79-93.

Green F (2001) It's Been a Hard Day's Night: The Concentration and Intensification of Work in Late Twentieth Century Britain. British Journal of Industrial Relations 39 (1): 53-80.

Green F (2004) Work Intensification. Discretion and the Decline of Well-being at Work. Eastern Economic Journal 30 (4): 615-625.

Green F (2008) Work Effort and Worker Well-Weing in the Age of Affluence" in Burke RJ and Cooper CL (eds) The Long Work Hours Culture: Causes, Consequences and Choices.

Bingley: Emerald Group Publishing.

Green F and McIntosh S (2001) The Intensification of Work in Europe. Labour Economics, 8:291-308.

Hewett SA and Luce CB (2006) Extreme Work and the Dangerous Allure of the 70-Hour Workweek. Harvard Business Review December: 49-59.

Hodgson D (2002) Disciplining the professional: The case of project management. Journal of Management Studies 39(6): 803-821.

Hodgson H (2004) Project Work: The Legacy of Bureaucratic Control in the Post-Bureaucratic Organization. Organization 11: 81.

Hodgson D and Cicmil S (2007) The politics of standards in modern management: Making 'the project' a reality. Journal of Management Studies 44(3): 431-450.

Jacques R (1996) Manufacturing the employee: Management knowledge from the 19th to 21st centuries. Sage.

Johns J (2006) Video game production networks: Value capture, power relations and embeddedness. Journal of Economic Geography 6: 151-180. 
Kalleberg AL (2009) Rethinking the Sociology of Work, Workers and the Workplace. Labour and Industry 19(3): 29-48.

Kane P (2004) The Play Ethic: A Manifesto for a Different Way of Living. London: Macmillan.

Kerr A (2006). The business and culture of digital games. London: Sage.

King N (1998) Template analysis. In G. Symon and C Cassell (Eds.), Qualitative Methods and Analysis in Organisational Research. London: Sage.

Lazzarato M (1996) Immaterial labortrans (trans Colilli P and Emory E) In Virno P and Hardt M (eds) Radical Thought in Italy. Minneapolis: University of Minnesota Press: 132-146.

Lazzarato M (2006) Construction of Cultural Labour Market (trans Viren E and Derieg A). In: A Critique of Creative Industries, Helsinki, Finland, Aug 31-Sept 2 2006. European Institute for Progressive Cultural Policies and Finnish Fund for Art Exchange.

Lazzarato M (2009) Neoliberalism in action: Inequality, Insecurity and the Reconstitution of the Social. Theory, Culture \& Society 26(6): 109-133.

Legault MJ and Bellemare G (2008) Theoretical Issues with New Actors and Emergent Modes of Labour Regulation. Relations industrielles/Industrial Relations 63(4): 742-768.

Legault MJ and Weststar, J (2014) Comment jouer la régulation dans l'industrie du jeu vidéo? Relations Industrielles/Industrial Relations 69(1): 136-158.

Legault MJ and Weststar J (2012) More than the Numbers: Independent Analysis of the IGDA 2009 Quality of Life Survey. Available at: http://gameqol.org (accessed July 142013 ).

Legault MJ and Weststar J (2013) Are Game Developers Standing up for their Rights? In Gamasutra Features. Available at:

www.gamasutra.com/view/feature/184504/are game developers standing up .php (accessed September 6 2013).

Martin CB and Deuze M (2009) The independent production of culture: A digital games case study. Games and culture 4(3): 276-295.

McKenna S (2007) Deconstructing a personal "academic"/“practitioner" narrative through selfreflexivity. Qualitative Research in Organizations and Management: An International Journal 2(2): 144-160.

McKenna S (2010) Managerial Narratives: A Critical Dialogical Approach to Managerial Identity. Qualitative Research in Organizations and Management: An International Journal 5(1): 5-27. 
McRae S (2003) Choice and constraints in mothers' employment careers: McRae replies to Hakim. The British Journal of Sociology 54(4): 585-592.

Neff G (2012) Venture labor: Work and the burden of risk in innovative industries. MIT Press.

O’Donnell C (2009) The Everyday Lives of Video game Developers: Experimentally Understanding Underlying Systems/Structures. Transformative Works and Cultures 2. Retrieved from http://journal.transformativeworks.org/index.php/twc/article/view/73

Ó'Riain S (2001) Net-working for a living: Irish software developers in the global workplace. $A$ critical study of work: labor, technology and global production, 258-282.

Peticca-Harris A and McKenna S (2013) Identity Struggle, Professional Development and Career: A Career/Life history of a Human Resource Management Professional. Journal of Management Development 32(8) 823-835.

Prasad A and Prasad P (1998) Everyday struggles at the workplace: The nature and implications of routine resistance in contemporary organizations. In SB Andrews and D Knoke (Eds.), Research in the Sociology of Organizations. Greenwich, CT: JAI Press.

Prasad A and Prasad P (1998) Stretching the iron cage: The constitution and implications of routine workplace resistance. Organization Science 11: 387-403.

Remo C (2010) IGDA Elections See Four New Board Members, One Reelection. Available at: www.gamasutra.com/view/news/27479/IGDA Elections See Four New Board Members One Reelection.php (accessed April 2, 2013).

Riessman CK (1993) Narrative Analysis. Newbury Park, CA: Sage.

Rockstar Spouse (2010) Wives of Rockstar San Diego employees have collected themselves. In: Gamasutra. Available at:

www.gamasutra.com/blogs/RockstarSpouse/20100107/4032/Wives_of_Rockstar_San_Diego_e mployees_have_collected_themselves.php (accessed: February 17, $201 \overline{3}$ ).

Rose M (2011) Modern Warfare 3 Grosses 775M Worldwide in 5 Days.” In: Gamasutra. Available at:

www.gamasutra.com/view/news/38619/Modern_Warfare_3_Grosses_775M_Worldwide_In_5 Days.php (accessed February 25 2013).

Ross A (2003) No Collar. The Humane Workplace and its Hidden Costs. Philadelphia: Temple University Press.

Schor JB (1991) The Overworked American: The Unexpected Decline of Leisure. New York: Basic.

Schumacher L (2006) Immaterial Fordism: The Paradox of Game Industry Labour. Work, 
Organization, Labour \& Globalization 1(1): 144-155.

Sennett R (2011) The corrosion of character: The personal consequences of work in the new capitalism. NY, NY: WW Norton \& Co.

Sewell G (2007) The Discipline of Teams: The Control of Team-Based Industrial Work through Electronic Peer Surveillance. Administrative Science Quarterly 41: 397-429.

Sinclair B (2013) EA Spouse says EA doesn't get enough credit. In: gamesindustry International. Available at: www.gamesindustry.biz/articles/2013-03-28-ea-doesn't-get-enoughcredit-says-ea-spouse (accessed February 10 2013).

Sturges J (2013) A matter of time: young professionals' experiences of long work hours. Work, Employment \& Society 27(2): 343-359.

Sturdy A, Fleming P, and Delbridge R (2010), 'Normative Control and Beyond in contemporary Capitalism' in Paul Thompson and Chris Smith (ed.), Renewing Labour Process Analysis, London: Palgrave.

Surette T (2006) EA Settles OT Dispute, Disgruntled "Spouse" Outed. In: Gamespot. Available at: www.gamespot.com (accessed March 3 2013).

Walker Rettberg J (2008) Blogging. Malden, MA: Polity Press.

Webb J (2004) Organizations, Self-Identities and the New Economy. Sociology 38(4): 719-738.

Westecott E (2013) Independent Game Development as Craft. Loading... 7(11). Available at: http://journals.sfu.ca/loading/index.php/loading/article/view/124 (accessed 25 May 2014).

Weststar J and Legault MJ (2012) Facts and discussion about hours of work in the video game industry. In Bracken A and Guyot N (eds). Cultural perspectives of video games: From designer to player. Oxford, UK: Interdisciplinary Press.

Whitson J (2013) The 'Console Ship is Sinking' and What this Means for Indies. Loading... 7(11). Retrieved from http://journals.sfu.ca/loading/index.php/loading/article/view/125

Williams D (2002) Structure and competition in the U.S. home video game industry. The International Journal on Media Management 4: 41-54.

Willmott H (1997) Rethinking Management and Managerial Work: Capitalism, Control and Subjectivity. Human Relations 50(11): 1329-1359.

Vosko LF (2000) Temporary Work: The Gendered Rise of a Precarious Employment Relationship. Toronto; Buffalo and London: University of Toronto Press. 
Zackariasson P, Walfisz M, and Wilson TL (2006) Management of creativity in video game development: A case study. Services Marketing Quarterly 27(4): 73-97. 